\title{
Public-private partnerships in the healthcare sphere: legal models in Ukraine and foreign countries
}

\section{ПУБЛІЧНО-ПРИВАТНЕ ПАРТНЕРСТВО СФЕРИ ОХОРОНИ ЗДОРОВЯ: ЮРИДИЧНІ МОДЕЛІ В УКРАЇНІ ТА ЗАРУБІЖНИХ КРАЇНАХ}

Received: February 4, 2021

Abstract

The article discusses certain aspects of the legal regulation of public-private partnerships in the health sector in Ukraine and foreign countries. The subject of the study is the legislative acts of public-private partnerships in healthcare field, its types and directions for their implementation. The varieties of public-private partnership forms in healthcare field in foreign countries and Ukraine are clarified. Process of reforming the healthcare sector, introduction of standards and criteria of best practices of European countries on the issues of partnership under study in national legislation is appropriate and promising.

The aim of the article is to disclose the features of legal regulation of public-private partnerships implementation in the healthcare field in foreign countries and Ukraine. The methodology of this work is based on a set of research methods. The comparative method was used to clarify the legal aspects of public-private partnerships in the healthcare field and the possibility of its use in Ukraine, to analyze indicators that determine the success of partnership projects in foreing countries. Using the method of theoretical
Accepted: March 5, 2021

Written by:

Shevchuk Oleksandr ${ }^{57}$

https://orcid.org/0000-0003-4864-7316

Zui Valentyna ${ }^{58}$

https://orcid.org/0000-0002-7856-5066

Kompaniiets Igor $^{59}$

https://orcid.org/0000-0002-0033-5009

Martynovskyi Volodymyr ${ }^{60}$

https://orcid.org/0000-0002-8666-7900

Matat Yurii ${ }^{11}$

https://orcid.org/0000-0002-5604-7241

\section{Анотація}

У статті розглядаються деякі аспекти правового регулювання публічноприватного партнерства в сфері охорони здоров'я в Україні та зарубіжних країнах. Предметом дослідження є законодавчі акти, наукові праці з питань публічно-приватного партнерства у сфері охорони здоров'я, його видів і напрямків реалізації. Уточнено різновиди форм публічно-приватного партнерства у сфері охорони здоров'я в країнах ЄС та Україні. Доведено, що процес реформування сектору охорони здоров'я України, впровадження стандартів i критеріїв передового досвіду європейських країн 3 досліджуваних питань публічноприватного партнерства в національному законодавстві є доцільним і перспективним. На практиці єдиної універсальної моделі публічно-приватного партнерства в системі охорони здоров'я не існує.

Метою статті $\epsilon$ розкриття особливостей правового регулювання реалізації публічноприватного партнерства в сфері охорони здоров'я у зарубіжних країнах і Україні.

\footnotetext{
${ }^{57}$ Doctor of Law sciences, Professor of the Department of Administrative Law and Administratively Activities, Yaroslav Mudryi National Law University, Kharkiv, Ukraine.

${ }^{58}$ Candidate of Law, Associate Professor of the Department of Administrative Law, Yaroslav Mudryi National Law University, Ukraine.

${ }^{59}$ Candidate of Law, Associate Professor of the Department of Administrative Law and Administratively Activities, Yaroslav Mudryi National Law University, Ukraine.

${ }^{60}$ Candidate of Law, Associate Professor of the Department of Administrative Law and Administratively Activities, Yaroslav Mudryi National Law University, Ukraine.

${ }^{61}$ Candidate of Law, assistant of the Theory and Philosophy of Law Department of Yaroslav Mudryi National Law University, Ukraine.
} 
analysis, systemic and analytical methods, the term of "public-private partnership in the healthcare field" was established, types of contracts, signs of public-private partnership, categories of such partnership models in world practice are given. Experience of the EU countries on public-private partnerships in healthcare field, the introduction of changes in healthcare management system in accordance with requirements of European law is positive for Ukraine.

Key Words: legal models, public-private partnership, health care, legal regulation in the EU public-private partnership.

\section{Introduction}

At the end of the twentieth century humanity has entered a qualitatively new stage in its development, which is determined, first of all, by the globalization of all spheres of society. Its main difference from all previous stages is the ambiguity of the main vector of further development...., (Danylian \& Dzoban, 2017). Important in this process of globalization is public-private partnership in various spheres of state activity, including the health sector.

Today, in the world practice of healthcare management, public-private partnership is a common model in countries with different levels of economic development and with different healthcare systems. The increased attention to the problems of public-private partnership in healthcare is due to the complexity of the implementation of the state policy of Ukraine in medicine. The introduction and use of publicprivate partnership projects in the healthcare sector will allow the most effective way to solve
Методологія роботи базується на дослідницьких методах. Порівняльний метод був використаний для з'ясування правових аспектів публічно-приватного партнерства в сфері охорони здоров'я i можливості його використання в Україні, а також для аналізу показників успішності партнерських юридичних моделей та проектів у країнах ЄC. Методом теоретичного аналізу, системними i аналітичними методами встановлений термін «публічне-приватне партнерство в сфері охорони здоров'я», охарактеризовані види договорів, розкрито ознаки публічноприватного партнерства, категорії таких юридичних моделей партнерства в світовій практиці. Досвід країн СС щодо публічноприватного партнерства в сфері охорони здоров'я може сприяти внесенню змін у систему управління охороною здоров'я України відповідно до вимог європейського законодавства, що позитивно вплине на розвиток законодавства України. Впровадження міжнародних юридичних практик публічно-приватного партнерства в Україні надасть можливості ефективніше реалізувати право громадян на доступ до якісних медичних послуг.

Ключові слова: юридичні моделі, публічно-приватне партнерство, сфера охорони здоров'я, правове регулювання в ЄС публічно-приватного партнерства.

social and medical problems, improve the quality of medical services and their availability.However, today the development of the concept of public-private partnership in the national health sector is not a priority issue of public policy. Thus, according to the World Health Statistics (2016), health spending in Ukraine is $7 \%$ of GDP (spending per citizen per year is \$ 141). This indicator is significantly lower than in economically developed countries, for example, the United States occupies the first place in terms of health care expenditures, where the volume of health care expenditures is $17 \%$ (\$9870 per one citizen per year).

The health care system in Ukraine is characterized by inadequate funding, low efficiency in the use of resources, and an unsatisfactory level of implementation of the state guarantee program for the provision of medical care (Medvedovska, 2010). Inadequate management and corruption are added to the 
problem of underfunding healthcare in Ukraine, which makes it impossible to receive quality medical services (Kravchenko, 2018). The growing dissatisfaction of the population of Ukraine with the quality and cost of medical services requires an increase in the efficiency of mechanisms for managing the healthcare system. International experience shows that for rapid economic development, in addition to adopting acts of national legislation in the field of publicprivate partnerships, it is necessary to use a mechanism of state support in order to attract private investment based on such partnerships (order of the Cabinet of Ministers of Ukraine No 739-r of August 14/2013).

The foregoing indicates the relevance of this study.The aim of the article is to disclose the features of legal regulation of public-private partnerships implementation in the healthcare field in foreign countries and Ukraine.

\section{Theoretical framework}

In this paper, we consider some aspects of the legal regulation of public-private partnerships in the field of healthcare in the countries of the European Union and the world in order to clarify the possibilities of use in Ukraine. So, in Ukraine, studies have already been conducted on certain issues of public-private partnership. So, Pavlyuk K., \& Kaminska O. (2018) drew attention to certain legal aspects of the implementation of foreign experience in public-private partnerships in the healthcare system. Kravchenko V. (2018) investigated the model of a consultative diagnostic center based on public-private partnerships. Brailovsky I. (2014) disclosed certain aspects of the theory and mechanism of development of public-private partnerships, etc. In foreign countries, issues of public-private partnerships were also studied. For example, Nishtar S. (2004) focused on public-private partnerships regarding health; Buse K. \& Waxman A (2001) examined WHO's involvement in the commercial sector, especially in partnerships. Silversides A. (2008) studied the experience of public-private partnerships in the provision of medical services in Canada. Thomason, J \& Rodney A. (2009) revealed public-private partnerships in Papua New Guinea (PNG) and highlighted the potential benefits that can be provided to communities through the further development of such public-private partnerships for health. Vrangbaek K. (2008) studied the Danish health sector and noted that the main actors in the public sector support the development of the concept of public-private partnerships in the health sector, but the regulatory framework for its development is somewhat uncertain. Tynkkynen, L. \& Lehto J. analyzed the ophthalmology services in Finland and indicated the possibilities of developing public-private partnership projects in this area. J. Du Toit (2003) showed that South Africa's health policy has four key objectives - equity, coherence, quality of care, and effectiveness which provide a useful basis for decision-making on public-private partnerships in healthcare. Ciccone D. (2010) considers public-private partnerships as a tool for engaging the private sector to effectively manage the public health sector. Along with this, despite the wide coverage of public-private partnerships in healthcare, taking into account the priority of the second stage of healthcare reform, there is a need for further development and study of the legal problems of interaction between the state and private partners in the healthcare sector.

\section{Methodology}

The purpose of the article is to disclose the features of the legal regulation of the implementation of public-private partnerships in health care in the EU, the world and in Ukraine. To achieve the goal of this work, it is necessary to perform the following tasks: (1) carry out a systematic analysis of scientific literature and the regulatory framework concerning the problem under study, domestic and foreign experience; (2) identify controversial issues on the disclosure of the content of the concept of "public-private partnership in health care"; (3) define the role and principles of public-private partnership of health care in Ukraine; (4) to reveal and determine the directions of the concept of the development of public-private partnership in the health care system in Ukraine using positive foreign experience.

\section{Results and discussion}

The history of the development of the process of interaction between a public and a private partner begins in ancient times, when the state transferred its powers to perform certain tasks to a private person for a certain fee. Since then, legal norms and principles governing partnerships between the public and private sectors, as well as specific forms of interaction between the state and entrepreneurs, have undergone significant transformations, but the general understanding and recognition of the need for such cooperation has become more responsible. In Ukraine, public-private partnership projects in the health sector are in their initial stage of development. The main 
arguments for the use of projects by the state on the terms of public-private partnership in the health sector are the limited budgetary resources in medicine, as well as the lack of experience of the state to effectively manage medical infrastructure in modern conditions of medical reform in Ukraine and the development of the market for providing medical services to the population. Formation of the legal institution of public-private partnership in the modern sense of this term began to develop in Europe since the 1980 , primarily in the Great Britain. In particular, the legal basis for public-private partnerships is the provisions of the United Nations Millennium Declaration, which was approved by General Assembly resolution 55/2 of September 8, 2000. The Monterrey Consensus, which was adopted at the International Conference on Financing for Development, held on March 18-22, 2002 in Monterey, (Mexico), is also important in the legal mechanism of public-private partnerships in the health sector. The essence of public-private partnership, as stated in these documents, is the implementation of public infrastructure measures aimed at sustainable development through project financing and project implementation using private investment and on the basis of transferring risks from the public sector to the private.

The problem of creating new opportunities for the development of the private sector with the use of public-private partnership mechanisms in the health sector is becoming increasingly important in our country. Ukraine has created a legal framework for the development of public-private partnerships in the health sector since 1999. There are laws on concessions, on production sharing agreements, on public-private partnerships and other laws that govern activities in areas. In Ukraine, in the second half of 2013, in total, 160 projects were launched on the basis of state-private partnership, but only three in the healthcare sector. In Ukraine, there are a number of obstacles to the implementation of publicprivate partnerships in the healthcare sector, such as the lack of state guarantees for political instability in the country, the main problem is the significant risk of investing in the healthcare sector, the personnel component in the field of public administration of the healthcare sector I am able to professionally assess long-term investment contracts in medicine are practically absent.

The legal basis for public-private partnership is the Constitution of Ukraine, the Civil Code of
Ukraine, the Economic Code of Ukraine, of the Law of Ukraine No. 2404-VI of 01 July, (2010), "On Public-Private Partnerships", other legislative acts of Ukraine, as well as international treaties of Ukraine, the consent to be bound by which was provided by the Verkhovna Rada of Ukraine. Law of Ukraine No. 2404-VI of 01 July, (2010), "On Public-Private Partnerships" defines the organizational and legal basis for the interaction of public partners with private partners and the basic principles of public-private partnerships on a contractual basis. In addition to legislative acts, certain issues of the development of public-private partnerships in the health sector are regulated by decrees and by orders of the Cabinet of Ministers of Ukraine, regulations and orders of central authorities executive power, decisions of local executive bodies and local government bodies. In general, only at the national level, there are three dozen normative acts directly regulating public-private relations in the field of healthcare.

In Ukraine, the need to disseminate the practice of public-private partnerships is declared in the Concept for the development of public-private partnerships in Ukraine for 2013-2018. The Concept proclaims that in the context of the aggravation of the global economic crisis, the private sector acquires the status of an equal partner of the state in fulfilling the strategic tasks of the country's socio-economic development (order of the Cabinet of Ministers of Ukraine No. 739-r of 14 August, 2013). The purpose of the Concept is to define a unified approach to the development of a mechanism for effective interaction between public authorities, local governments, the private sector and civil society institutions on the principles of public-private partnership to ensure the successful implementation of projects aimed at improving the indicators of the national economy, the quality of life of the population and the state the surrounding natural environment.

The growing interest in public-private partnerships in the healthcare sector is explained by the fact that in many countries it can effectively solve the problem of improving the quality of medical services by combining the resources of the public and private sectors. So, for example, the share in the total financing of public-private partnership between the countries of the European Union is: in Germany and Ireland - $1 \%$, the Netherlands - 3\%, Italy - 5\%, Spain - 8\%, Greece - 10\%, Portugal - 19\%, Denmark and Sweden - 25\%, Great Britain - 28\% (Matyukhina, 2015) verified. So, in the World 
Statistical Report for 2013 the following indicators of volumes of health financing are presented: Great Britain - 9.0\%, Brazil 10.0, Germany - $11.0 \%$, Canada - $11.0 \%$, USA $17.0 \%$ of GDP (gross domestic product) (Avvakumov, 2015).

On the territory of the European Union, a publicprivate partnership is defined as "transferring to the private sector a part of the powers, responsibility and risks for the implementation of investment projects that were traditionally implemented or financed by the public sector"or as "a system of relations between a public authority (management) and a private organization, in which the latter is given a large role in planning, financing and the implementation of a specific service for the public, rather than using traditional cooperation procedures (for example, tendering), and less than during the use of the privatization mechanism. At the same time, the protection of state and communal interests is guaranteed through the institutional framework, provisions of regulatory acts and concluded contracts. According to the approaches of the European Commission, the main role of the private sector in public-private partnership projects in solving health problems will be: (1) formation of joint investment resources of the public and private sectors to achieve socially significant health outcomes; (2) increasing the efficiency of using state property on the basis of entrepreneurial motivation; (3) improvement and creation of new systems and methods of management of medical institutions; (4) reducing the cost of healthcare projects; (5) efficient distribution of risks and increasing the profitability of projects. In turn, the role of the state in social and medical projects of public-private partnership will be determined in: (1) improving the quality of medical services to the population; (2) ensuring a better definition of needs and optimal use of the resources of the state, private partner, public organizations and the consumer of medical services; (3) providing favorable conditions for the private sector for the development of social and medical projects (for example, land acquisition for the construction of medical centers, clinics, diagnostic centers, rehabilitation institutions; (4) issuing licenses for opening medical and pharmaceutical businesses, (5) providing state guarantees, subsidies, soft loans, etc.); (6) stimulating innovation through competition mechanisms; (7) ensuring legal regulation of public-private relations in the development of the healthcare sector (European commission directorate-general regional policy, 2003)
Public-private partnerships create the opportunity to improve the level of health, maintain social stability in society, improve the quality of medical care to the level of world standards, optimize government spending and minimize structural imbalances, thereby acting as an effective tool in reforming the healthcare system (Mcintosh et al, 2015). Many researchers note that public-private partnerships were seen as a mechanism for mobilizing additional resources and supporting health care activities. There is another point of view. So, S. Nishtar indicates that the public opinion is somewhat uncertain regarding private service providers (Nishtar, 2004). Richter J. (2004) argues that publicprivate partnerships alone are not necessarily positively innovative, but that many of them carry great risks that are not identified and addressed. Asante A. \& Zwi A. (2007) pose many concerns regarding the impact of publicprivate partnerships on health equity.

There are many definitions of the term "publicprivate partnership". In the scientific literature of certain countries, there are certain advantages in terms of use of the term "public-private partnership": in continental Europe the abbreviation PPP (Public-Private Partnership) is used in the USA and Canada - designation P3 or less often - P-P Partnerships; In Great Britain the term "private financial initiative" is used Initiative - PFI) in France, the term is used to refer to PPP "Concession"; various variations of the name of relations between the state and private business used in Scandinavia, Denmark, Australia and other countries. Thus, the World Bank points out that "public-private partnerships are an agreement between public and private parties regarding the production and provision of infrastructure services concluded with the aim of attracting additional investments and, more importantly, as a means of increasing the effectiveness of budget financing" (United Nations Economic Commission for Europe, UN, 2008). According to the provisions of the Law of Ukraine No. 2404-VI of 01 July, (2010), “On Public-Private Partnerships", healthcare is one of the areas of application of public-private partnership mechanisms in Ukraine (Art. 4 Law of Ukraine 01 July of 2010 No. 2404-VI). This Law defines the legal structure of "public-private partnership" - cooperation between the state of Ukraine, territorial communities represented by relevant state bodies and local self-government bodies (state partners) and legal entities except state and communal enterprises, or individuals entrepreneurs (private partners). Such cooperation is carried out on the basis of an agreement in the manner prescribed by this Law 
and other legislative acts, and meets the signs of public-private partnership defined by this Law (Art. 1 Law of Ukraine of July 01. 2010 No 2404VI).

From the point of view some authors publicprivate partnerships should be considered a public-private partnership only if such signs of public-private partnership are observed as pooling contributions, sharing risks, sharing benefits between partners, etc. The authors propose introducing the term "public-private cooperation" into legal circulation (Lokhtina \& Batuev, 2010). Other authors believes that public-private partnerships are a strategic, institutional and organizational alliance between government and business in order to implement socially significant projects in a wide range of areas: from basic industries to the provision of public services Varnavsky V. (2005). There is also a point of view of researchers that define the category of "public-private partnerships" as more or less permanent cooperation between public and private entities, through which joint products or services are developed and in which risks, costs and profits are distributed (Tynkkynen \& Lehto, 2009).

In studies, some scholars believe that the use of the term "public-private partnership" in the healthcare system should be considered from the perspective of market relations in the medical field, where the leading role of the state is clearly defined Vovk S. (2016). According to others the interaction of the state and private business in the field of health can be manifested in the direct participation of private medical institutions in providing free medical care for the population, for example, providing free assistance for the population under the state order . (Sinisammal, Leviäkangas, Autio \& Hyrkäs, 2016) or that "public-private partnership in the healthcare system" is a contractual relationship between the state and private partners, the purpose of which is long-term mutually beneficial cooperation and achievement of both economic and social results in the provision of high-quality medical services to the population (Kravchenko, 2018).

From our point of view, public-private partnership in the field of healthcare is a legally fixed form of interaction between the state and the private sector in the form of an agreement regarding objects of state and communal ownership of the healthcare system, as well as educational and medical services in the healthcare sector. This agreement has a longterm nature (5-50 years). Risks, costs and resources are shared between partners. This form of interaction between the state and the private sector is more effective and efficient, as well as less costly than if the partners acted independently. After the end of the contract, the object of public-private partnership in the field of healthcare remains in state ownership. Three areas of development of public-private partnerships in the health sector can be distinguished: 1) the infrastructure of public facilities and local governments of the health system; 2) the provision of educational services in the healthcare system; 3) the provision of medical services.

The principles of health protection are general provisions, the main requirements, the most important of which are enshrined in legislation. So, according to art. 4 (Law of Ukraine No. 2801XII 19 of November, 1992) "Fundamentals of the Ukrainian Legislation on Health Care" it is indicated that the basic principles of health protection in Ukraine are as follows: 1) recognition of healthcare as a priority area of activity of society and the state, one of the main factors in the survival and development of the people of Ukraine; 2) observance of human and civil rights and freedoms in the field of health protection and provision of related state guarantees; 2) humanistic orientation, ensuring the priority of universal human values; 3) equality of citizens, democracy and general availability of medical care and other services in the field of health care; 4) compliance with the tasks and level of socio-economic and cultural development of society, scientific validity, material, technical and financial security; 5) focus on modern standards of health and medical care; 6) the multichannel nature of the health care economy and the multichannel nature of its financing, a combination of state guarantees for demonopolization and the promotion of entrepreneurship and competition; 7) decentralization of public administration, development of self-government of institutions and the independence of health workers on a legal and contractual basis.

In order to ensure the effective implementation of public-private partnership in the field of health care in Ukraine, the public and private sectors should rely on the following principles: 1) equal distribution of risks between partners; 2) saving budget funds; 3) innovative development of domestic medicine in order to provide patients with quality medical services; 4) formation of a mechanism for interaction between the state and business structures on the basis of voluntary and 
complementary partnerships; 5) obtaining economic and social effects 6) development of innovative forms of project management; 7) stimulating entrepreneurship and demand; 8) formation of an effective regulatory framework for regulating relations between partners; 9) information support of subjects of public-private partnership; 10) training of medical and management personnel in the implementation of medical and social projects of public-private partnership; 11) ensuring the unity of interests of partners (Martyakova \& Trikoz, 2013).

According to Art. 3 Law of Ukraine No. 2404-VI of 01 July, (2010), "On Public-Private Partnerships" the basic principles of publicprivate partnership implementation include: (1) equality before the law of public and private partners; (2) prohibition of any discrimination against the rights of public or private partners; coordination of interests of public and private partners in order to obtain mutual benefits; (3) ensuring higher efficiency of activities than when such activities are carried out by a public partner without involving a private partner; (4) invariability during the entire term of the contract concluded within the framework of the public-private partnership, the purpose and form of ownership of objects in state or communal ownership, transferred to the private partner; (5) recognition by public and private partners of the rights and obligations stipulated by the legislation of Ukraine and determined by the terms of an agreement concluded within the framework of a public-private partnership; (6) fair distribution between public and private partners of the risks associated with the execution of contracts concluded within the framework of public-private partnerships; (7) determination of a private partner on a competitive basis (Law of Ukraine No. 2404-VI of 01 July, 2010).

From our point of view, the principles of publicprivate partnership in health care should be divided into two groups: 1) general and 2) special. The first are the principles inherent in both public-private partnerships in health care and other branches of law, and special ones are only characteristic of public-private partnerships in health care. The first group includes the principles: the rule of law, legality, openness, publicity and transparency, professionalism and competence, inevitability of responsibility, respect and observance of human and civil rights and freedoms, impartiality and justice, controllability and accountability to society, etc. Special principles of public-private partnership in the healthcare sector: equality before the law of the public and private partners; prohibition of any discrimination of the rights of public or private partners; coordination of interests of public and private partners in order to obtain mutual benefits; invariability during the entire term of the agreement concluded within the framework of the public-private partnership, recognition by public and private partners of the rights and obligations provided for by the legislation of Ukraine, fair distribution between public and private partners of the risks associated with the execution of contracts concluded within the framework of public-private partnership in the field of healthcare, etc.

Analyzing the global experience of publicprivate partnerships, some scientists define 4 types of interaction in projects of state-legal partnership: 1) concessions; 2) new projects or projects from scratch; 3) sale of assets; 4) sale of assets (full and partial privatization) (Matviishyn \& Fabryka, 2014). Other researchers indicates that in world practice there are three main forms of public-private partnership: 1) contracts, an administrative contract on public-private partnership; 2) rent in its traditional form and in the form of leasing; 3) concession agreement. There is also a point of view of scientists that identifies 4 types of models of public-private partnerships, which include the following: 1) management and lease agreements (management contract, lease agreement); 2) concessions or management and operating contracts with large private capital obligations (projects of the type: ROT, RLT, BROT); 4) complex projects (projects of the type: BLO, BOT. BOO) sale of assets (full, partial) (Mataev, 2014). Despite this diversity regarding the understanding of the term public-private partnership by scientists, two main types of public-private partnerships in the health sector should be distinguished: (1) institutional, which refers to all forms of joint venture between public and private stakeholders; and (2) contractual, represented by the concession model.

The Law of Ukraine No. 2404-VI of 01 July, (2010), "On Public-Private Partnerships" stipulates that in the framework of public-private partnerships, agreements may be concluded on: (1) concessions, (2) joint activities, (3) other agreements (Art. 5 Law of Ukraine of July 01. 2010 No. 2404-VI). According to the provisions of this law, the privatization of healthcare facilities in Ukraine is prohibited. Contracts for public-private partnerships in the field of healthcare should correspond to the signs of public-private partnerships, namely: (1) creation, construction of an object of such a partnership 
and management (use, operation, maintenance) of such an object; (2) the duration of the relationship (from 5 to 50 years); (3) transfer of a part of the risks to the private partner; 4) making a private partner invest in a publicprivate partnership (Art. 1 Law of Ukraine No. 2404-VI of 01 July, 2010).

In the future, we will consider the experience of implementing public-private partnerships in the field of healthcare in the UK, Canada and Australia. So, in the UK public-private partnerships are actively implemented in the healthcare sector. From 1997 to March 2008, 70 priority public-private partnership projects in healthcare were implemented in this country. If in general for European countries for the period 2001-2008. contracts were signed under the scheme of public-private partnership for 36.5 billion euros, then in the UK for the same time at 611 billion euros (Panova, 2015) . The most commonly used option is public-private partnership, when healthcare facilities remain in state ownership - and this is a feature of contracts concluded in the UK under the model of "Private Finance Initiative" (Sachek, Kheifets \& Petrov, 2016). British National Health Service it is an example of a state financing model combined with effective market mechanisms; it represents a centralized version of a system built on the principle of a single payer in the person of the state, directly pays for the medical services provided and finances healthcare through tax budget revenues (Radionova, 2012).

Public-private partnership projects in the social sphere have been most successfully implemented in Canada, where they work well in the country's healthcare system. These partnerships combine the resources and medical experience of the public sector with the operational characteristics of the private sector (Ibyatov, 2019). For example, in Canada, based on the principles of public-private partnership, a new center, the Hospitalier de l'Université de Montréal, was built, worth $\$ 2$ million, the first stage of construction of which was completed in 2017. This Center combined three old hospitals (SaintLuc, l'Hotel -Dieu and Notre-Dame) in the very center of Montreal (MISMMPP -2019). (Ibyatov, 2019). The Hospitalier de l'Université de Montréal has become Canada's largest healthcare project. In 2004, the National Australian PPP forum was created in Australia, which is the main mechanism for coordination and cooperation of national, provincial and local authorities and acts as a coordinator of work in the partnership sphere not only of ministries, but also of business (Donato, 2010). Australia's healthcare system has transferred state-private partnership projects to state level, and in Australia, the cost savings for building hospitals using such projects are $9-11 \%$ (Blanken \& Dewulf, 2010). In Australia, as a result of health care reform, the cost of building new hospitals decreased by $20 \%$, and the number of patients served increased by $30 \%$ per year (Zainasheva \& Sabirova, 2013).

In the EU countries, in the health sector in 2013, 12 projects were implemented in the amount of 1.5 billion euros (382 million euros in 2012), so the number of public-private partnership projects increased (Brailovsky, 2014). Let us further consider the experience of public-private partnerships in the health sector in individual EU countries. So, in Italy, the beginning of publicprivate partnership in the context of the provision of services in the social sphere was laid in 1923. The first concession law was issued in Italy this year, and the first public-private partnership projects in the healthcare sector started in 1998. Already in 1999, individual public-private partnership projects in the healthcare sector were introduced in the amount of approximately $€ 6$ billion. This allowed Italy to take third place in the world in terms of investment in healthcare after the UK and Canada (Torchia \& Calabria, 2018). As of 2011, 50 public-private partnership projects had already been implemented in Italy in the healthcare sector, mainly for large hospitals and nursing homes. About 30 of these projects related to the creation of medical centers with 600 beds or more for a total of 350,000,000 Euros (Cappellaro, Ghislandi \& Anessi-pessina, 2011). The health care costs in Italy in public-private partnership projects amount to $50 \%$ of the regional budgets (as of 2014, 110 billion euros). The use of public-private partnership projects allows up to $60 \%$ of healthcare costs to be covered by private investment (Cappellaro \& Longo, 2011).

In Italy, the forms of public-private partnerships in the field of healthcare are concessions, which are expressed as: (1) public initiative; (2) private sector initiatives; (3) as service contracts, which include large construction projects and related only to the provision of medical services (Matevosyan, 2013). In France, for example, a public-private partnership is a project for 1000 beds, the Center Hospital de Sud Fracilien, with a hospital. The competition for the project was won by Eiffage, one of the largest construction and concession groups in France. The contract for the construction of the Center Hospital de Sud 
Fracilien took only six weeks, and the total cost of the public-private partnership project amounted to 315 million euros. The program of this partnership was designed for 30 years from the date of commencement of commercial use of the facility (including the construction period four years). The property has been in operation since 2012 and is state property (Gafurova, 2013).

In Sweden, public-private partnership projects since 2007 in the field of healthcare have been implemented to improve the provision of primary health care. In Sweden, already in 2010, 223 new primary care centers were created, which amounted to $23 \%$ of the entire system of preschool health care facilities. New health facilities for primary care have been opened in the most populated areas. In 2010 a competition authority was established in three major district councils / regions of Stockholm, the Skåne and Västra Götaland regions (Anell, Glenngård \& Merkur, 2012). Since 2010, the Swedish National Health Act has been amended in Sweden to allow people in the 21st district of Sweden to choose their primary health care provider and to allow private providers of such services to freely set methods if they meet certain standards. With regard to outpatient health services (e.g., dermatology, ophthalmology and physiotherapy), the decision of the counties to introduce a plan for choosing such services is voluntary (Ekman \& Wilkens, 2015).

The Institute for Public-Private Partnerships in Germany began to develop in 2002, after the establishment of public-private partnership centers. In 2005, the Law on Accelerating the Implementation of Public-Private Partnerships was adopted, which implied the widespread establishment of public-private partnerships in Germany, as well as the opening of the German Partnership consulting company (Suchich, Rudenko \& Oborina, 2013). The German federal healthcare system stipulates that in clinics the rate of return cannot be lower than $25 \%$. The purpose of this standard is to enable continuous updating of medical equipment. According to this norm, pricing is carried out in the German health care system. At the same time, a high level of salaries of medical personnel was established, which reaches $55 \%$ of all expenses of a medical institution (Panova, 2015). So, a successful example of public-private partnership in Germany is the construction of the largest proton therapy center in Essen. The cost of this project amounted to 132 million euros. The center was transferred to private management for 15 years with a planned cost savings of $20 \%$. The project was completed in 2010. Since then, approximately 2,200 patients have been treated at the Proton Therapy Center in Essen every year (Gafurova, 2013).

The specific features of public-private partnership projects in the field of healthcare in Ukraine are the following: (1) a ban on reducing the network of state and communal healthcare institutions (the transfer of the corresponding facility to a private partner should not result in the loss of the ability to provide medical services to public or communal healthcare institutions); (2) a special structure of the subjects of relations, because the side of the state partner must be represented either at the level of the Ministry of Health of Ukraine (for state-owned objects under its management) or local government bodies (for communal property); (3) the need to balance the social and commercial components of the project (return on investments of the private partner is carried out, as a rule, through the provision of paid services); (4) constitutional restrictions on the payment for services in state and communal healthcare institutions, the completeness of the list of paid services that are provided in state and communal healthcare institutions and higher medical educational institutions. Also, the health care system of Ukraine is in the conditions of medical reform, then structuring any project, public-private partnership in this area will require taking into account the following aspects: (1) processes of autonomization of healthcare institutions; (2) planned transition to financing medical services depending on the types of medical care; (3) the requirements of the National Health Service of Ukraine to providers of medical services for the population; (4) processes of formation of hospital districts and some other aspects. (Ilyk R et all. 2018).

\section{Conclusions}

The development of the healthcare sector of Ukraine in the context of medical reform without the use of a modern legal mechanism for the development of public-private partnership projects is impossible. An analysis of the principles of introducing public-private partnerships in the healthcare system in different countries of the world has made it possible to conclude that in practice there is no single universal model for such partnerships in the healthcare system.

So, in Sweden, public-private partnership projects in the healthcare sector were implemented in the direction of primary health care, in France, Germany, Italy, Canada - for the 
construction of large hospitals. It can be used in Ukraine. So, new modern healthcare facilities have not been built in recent decades. Positive for Ukraine is the experience of public-private partnerships in the UK according to the "Private Finance Initiative" model, when healthcare facilities remain in state ownership due to the fact that the privatization of healthcare facilities in Ukraine is prohibited. In Ukraine, it is advisable to create a single body, which is the main coordinator of the work of the health sector in the field of public-private partnerships not only of ministries, but also of business, as well as coordination and cooperation of national and local authorities and local authorities (Australian experience). World experience also points to the economic efficiency of using public-private partnerships in the healthcare system: 1) in Germany, cost savings were $20 \%$; 2) in Italy, the use of projects has allowed up to $60 \%$ of expenditures in the healthcare sector to be provided through private investment, 3 ) in Australia, as a result of health care reform, the cost of building new hospitals fell by $20 \%$.

The imperfection of the legislative regulation of public-private partnerships in the healthcare sector in Ukraine and the lack of smooth functioning of state regulation mechanisms hinder its development. To increase the number of public-private partnership projects in healthcare, guarantees of public-private partnerships, legal opportunities to attract private investment in the development of the blood service, hospice care and so on should be establishedImproving the legal aspects of publicprivate partnerships in Ukraine using the experience of leading European countries will help to more effectively realize the right of citizens to access quality medical services.

\section{Bibliographic references}

Anell A., Glenngård, A., Merkur, \& Sweden, S. (2012) Health system review. Health Syst. Transit, No.14 (5), pp.1-159.

Asante A., \& Zwi, A. (2007). Public-private partnerships and global health equity: prospects and challlenges. Indian J Med Ethics, No. 4(4), pp. 176-180. doi: 10.20529/IJME.2007.070

Avvakumov, A. (2015). Designing models of public-private partnership in the implementation of innovation. Public-private partnership, No.2, pp. 61-74.

Blanken A. \& Dewulf G. (2010). PPPs in health: static or dynamic? Australian Journal of Public Administration, vol.69, No.1, pp.35- 47.
Brailovsky, I. (2014) Public private partnership: methodology, theory, mechanisms of development (Thesis Doctor of Economics). Donetsk national university. Donetsk . Retrieved from:

https://sp.nmu.org.ua/d_08.080.01/\%D0\%91\%D $1 \% 80 \% \mathrm{D} 0 \% \mathrm{~B} 0 \% \mathrm{D} 0 \% \mathrm{~B} 9 \% \mathrm{D} 0 \% \mathrm{BB} \% \mathrm{D} 0 \% \mathrm{BE}$ $\% \mathrm{D} 0 \% \mathrm{~B} 2 \% \mathrm{D} 1 \% 81 \% \mathrm{D} 1 \% 8 \mathrm{C} \% \mathrm{D} 0 \% \mathrm{BA} \% \mathrm{D} 0 \%$ B8\%D0\%B9\%20\%D0\%86.\%D0\%90._\%D0\%9 4\%D0\%B8\%D1\%81\%D1\%81\%D0\%B5\%D1\% 80\%D1\%82\%D0\%B0\%D1\%86\%D0\%B8\%D1 $\% 8$ F.pdf

Buse K. \& Waxman, A. (2001) Public-private health partnerships: a strategy for WHO. Bulletin of the World Health Organization, No. 79(8), pp. 748-754.

Cappellaro G., \& Longo, F. (2011) Institutional public private partnerships for core health services: evidence from Italy. BMC Health Services Research, Vol. 11(82). https://doi.org/10.1186/1472-6963-11-82

Cappellaro G., Ghislandi, S., \& Anessi-pessina, E. (2011). Diffusion of medical technology: the role of financing. Health Policy, Vol. 100(1), pp. 51-59. doi: 10.1016/j.healthpol.2010.10.004

Ciccone, D.K. (2010). Arguing for a centralized coordination solution to the public-private partnership explosion in global. Global Health Promotion, Vol. 17(2), pp.48-51.

Donato, R. (2010). Extending transaction cost economics: towards a synthesised approach for analysing contracting in health care markets with experience from the Australian private. Social Science \& Medicine, 71(11), pp. 1989-1996. doi: 10.1016/j.socscimed.2010.09.016

Danylian, O. G., \& Dzoban, O. P. (2017). Globalization of culture: contradictions and development trends. The Bulletin of Yaroslav Mudryi National Law University. Series:Philosophy, philosophies of law, political science, sociology, Vol. 2(33), pp. 29-40.

Du Toit, J. (2003). Public-private Partnerships insights in South Africa. World Hospitals and Health Services Journal, No. 39(1), pp. 2-32.

Ekman, B., \& Wilkens, J. (2015) A literature review of the regional implementation of the central Swedish government's health care reforms on choice and privatization. Health economics review, No.5(39), pp.1-5. https://doi.org/10.1186/s13561-015-0076-0

European commission directorate-general regional policy (2003). Guidelines for Successful Public-Private Partnerships, 100 p. Retrieved from:

https://ec.europa.eu/regional_policy/sources/doc gener/guides/ppp_en.pdf 
Gafurova, H. (2013) Foreign experience in the development of public-private partnership mechanisms. Finance and credit, 48, pp. 62-72. Ilyk, R., Litovchenko, I., Slobodnichenko, M., Pitel, L., \& Korchakova-Hib, N. (2018) Guidelines for the implementation of publicprivate partnership projects in the field of health care: for state and communal healthcare institutions, for employees of management bodies in the field of health protection. Ministry of Health of Ukraine, $72 \mathrm{p}$. Retrieved from: https://moz.gov.ua/uploads/1/7840-

1234567890.pdf

Ibyatov, F. (2019) Foreign experience in implementing public-private partnership projects in the field of healthcare and education. Upravlenie.. no. 7(1), pp. 35-39. (In Russ.) https://doi.org/10.26425/2309-3633-2019-1-3539.

Kravchenko, V. (2018) Medical and social justification of the conceptual model of the consultative diagnostic center on the principles of public-private partnership. (Thesis doctor of medical sciences), National Medical Academy of Advanced Studies P.L. Shupika, Kyiv. 442 p. Retrieved from: https://nmapo.edu.ua/zagruzka2/DrAr/Dr_Kravc henko.pdf

Law of Ukraine No. 2404-VI. On Public-Private Partnerships. Information of the Verkhovna Rada of Ukraine of 08 0ctober, 2010, № 40. Art. 524. Law of Ukraine No. 2801-XII 19 of November, 1992. Fundamentals of Ukrainian legislation on health care. Information of the Verkhovna Rada of Ukraine. 26 of January 1993. № 4. Art. 19. Retrieved from: https://zakon.rada.gov.ua/laws/show/280112\#Text

Lokhtina, L., \& Batuev, E. (2010). The concept and essence of public-private partnership. Social aspects of public health, No. 15(3). Retrieved from:

http://vestnik.mednet.ru/content/view/212/lang,r $\mathrm{u} /$

Martyakova, O., \& Trikoz I. (2013) Mechanism of realizing state-private partnership in the sphere of health protection. Chasopis ekonomichnykh reforms, No. 4 (12), pp. 33-39.

Mataev, T. (2014) Definition and classification of forms of public-private partnership. Russian Entrepreneurship, No. (15) 7. pp. 51-58. (In Russian)

Matevosyan, A. (2013). Forms of public-private partnership in city infrastructure. Economic journal, No. 5, pp. 125-133.

Matviishyn, E., \& Fabryka, Y. (2014) Conditions for the implementation of public-private partnership in Ukraine. Efficiency of Public Administration, No. 40, pp.126-134.
Matyukhina, Y. (2015). Analysis of models of public-private partnership in health care of the Russian Federation. Economic science issues Questions of Economic Sciences, No. 6(76), pp. 58-61. (In Russian)

Mcintosh, N., Grabowski, A., Jack, B., NkabaneNkholongo, E., \& Vian T. (2015). A publicprivate partnership improves clinical performance in a hospital network in Lesotho. Health Aff, Vol. 34, No. 6. pp. 54-62.

Medvedovska, N. (2010) Assessment of the dependence of the dynamics of the health of the adult population on the network and staffing of health care institutions in Ukraine. Ukraine. Health of the nation, No. 4, pp. 55-59.

Nishtar, S. (2004). Public - private 'partnerships' in health - a global call to action. Health Research Policy and Systems, 2, 5, https://doi.org/10.1186/1478-4505-2-5.

Order of the Cabinet of Ministers of Ukraine: № 739-r: On approval of the Concept for the development of public-private partnership in Ukraine for 2013-2018. Of 14 August 2013. Official Gazette of Ukraine, 2013. № 76. Art. 2831.

Panova, T. (2015) The experience of developed European countries in the use of forms and models of public-private partnerships in healthcare. Questions of economics and law, No. 11, pp. 99-102.

Pavlyuk, C., \& Kaminskaya, O. (2018). Foreign experience in the development of public-private partnerships in the health care system. Scientific works of the Research Financial Institute, No. 2, pp. 117-132.

Radionova, O. (2012) Anglo-Saxon model of public-private partnership. News of the Irkutsk State Economic Academy, No. 4, pp. 113-116.

Richter, J. (2004). Public-private Partnerships for Health: A trend with no alternatives?. Development, No. 47, pp. 43-48 https://doi.org/10.1057/palgrave.development.1 100043

Sachek, M., Kheifets, N., \& Petrov, V. (2016) Public-private partnership in healthcare: international experience. Issues of organization and informatization of healthcare, No.1, pp. 18-34. (In Russian)

Silversides, A. (2008). Public-private partnerships, part 1: the next hospital wave. Canadian Medical Association journal, No. 179(9), pp. 883-885. https://doi.org/10.1503/cmaj.081540

Sinisammal, J., Leviäkangas, P., Autio, T., \& Hyrkäs E. (2016). Entrepreneurs' perspective on public-private partnership in health care and social services. Journal of Health Organization and Management. Vol.30, No.1, pp. 174-191. 
Suchich, V., Rudenko, M., \& Oborina, E. (2013). Public-private partnership: the experience of Russia and Germany. Bulletin of Perm University. Series: Economics, No. 3(18).

Thomason, J., \& Rodney, A. (2009). Publicprivate partnerships for health--what does the evidence say?. P N G Med J. No. 52(3-4). pp. 166-178.

Torchia, M. \& Calabria, A. (2018). Increasing the Governance Standards of Public-Private Partnerships in Healthcare. Evidence from Italy Public Organ. Rev, No. 12, pp. 93-110.

Tynkkynen, L \& Lehto, J. (2009). An analysis of ophthalmology services in Finland - has the time come for a Public-Private Partnership?. Health Research Policy and Systems, No. 7, pp. 24. doi: 10.1186/1478-4505-7-24.

United Nations Economic Commission for Europe (2008). Gguidebook on promoting good governance in public-private partnerships. New York and Geneva: United Nations Publications,
104 p. $\quad$ Retrieved from https://unece.org/fileadmin/DAM/ceci/publicati ons/ppp.pdf

Varnavsky, V. (2005) Public-private partnership: forms, projects, risks. M.: Nauka,. $315 \mathrm{p}$.

Vovk, S. (2016). Institutional definitions of understanding public-private partnership in medicine. State and regions. Series: Public Administration, No.3 (55), pp. 23 - 27.

Vrangbaek, K. (2008). Public-Private Partnerships in the health sector: the Danish experience. Health Economics, Policy and Law, No. 3(Pt2), pp. 141-163. doi: 10.1017/S1744133108004465

Zainasheva, Z., \& Sabirova Z. (2013) Foreign experience of public-private partnerships in the social sectors of the service sector. Bulletin "Ufa State Academy of Economics and Service". Economics, No.2, pp. 92-99. 